\title{
PENGARUH BIAYA PRIBADI (PRIVATE COST) DAN PERSEPSI SISWA TENTANG PEMBELAJARAN EKONOMI MATERI AKUNTANSI TERHADAP HASIL BELAJAR SISWA SMA
}

\author{
Beti Mawarnia, Pascasarjana Unesa \\ bettymawarnia@yahoo.com
}

\begin{abstract}
ABSTRAK
Penelitian ini bertujuan untuk menganalisis pengaruh biaya pribadi terhadap hasil belajar, menganalisis pengaruh persepsi siswa tentang pembelajaran ekonomi terhadap hasil belajar, serta menganalisis pengaruh biaya pribadi dan persepsi siswa tentang pembelajaran ekonomi terhadap hasil belajar.Penelitian ini merupakan jenis penelitian asosiatif kausal dengan pendekatan kuantitatif. Populasi dalam penelitian ini adalah siswasiswa kelas XI jurusan IPS dari SMAN 1, SMAN 2 dan SMAN 3 Kota Mojokerto angkatan tahun 2013/2014. Jenis pengambilan sampel yang digunakan dalam penelitian ini adalah Simple Random Sampling dan jumlah sampel yang digunakan sebanyak 255 siswa. Adapun metode pengumpulan data yang digunakan adalah metode kuesioner atau angket dan dokumentasi. Sedangkan metode analisis menggunakan teknik analisis regresi linier berganda. Berdasarkan hasil penelitian dapat disimpulkan bahwa secara parsial variabel biaya pribadi $\left(\mathrm{X}_{1}\right)$ berpengaruh signifikan terhadap hasil belajar demikian juga variabel persepsi siswa tentang pembelajaran ekonomi $\left(\mathrm{X}_{2}\right)$ secara parsial berpengaruh signifikan terhadap hasil belajar (Y). Sedangkan secara simultan biaya pribadi dan persepsi siswa tentang pembelajaran ekonomi berpengaruh terhadap hasil belajar. Dari hasil penelitian yang telah dijabarkan sebelumnya, maka peneliti merekomendasikan agar siswa mengoptimalkan alokasi biaya pribadi untuk pendidikan dan memiliki persepsi tentang pembelajaran ekonomi secara positif sehingga hasil belajar yang didapat lebih optimal lagi.

Kata Kunci: Biaya Pribadi, Persepsi Siswa, Hasil Belajar.
\end{abstract}

\begin{abstract}
This research aims to (1) analyze the effect of private cost on learning outcomes, (2) analyze the influence of students 'perceptions of the economic lesson on learning outcomes, (3) analyze the effect of private cost and students' perception of economic lesson on towards learning outcomes. This research is an associative causal research with a quantitative approach. Population in this research is the students of XI class majoring in social studies from SMAN 1, SMAN 2 and SMAN 3 Mojokerto year 2013/2014. The type of sampling which used in this study is simple random sampling and the number of samples that used as many as 255 students. The data collection method which used was the method of a questionnaire and documentation. While the methods of analysis using
\end{abstract}


multiple linear regression analysis technique. Based on the results of this study concluded that in partial private cost (X1) significantly affects learning outcomes as well as the students' perception of economic lesson (X2) partially has a significant effect on learning outcomes (Y). While simultaneously the private cost and economic perceptions of students about the learning effect on learning outcomes. From the research that has been described previously, the researchers recommend that students optimizing the allocation of private costs for education and learning have a perception of the economy as a positive study results obtained more optimally.

Keywords: Private Cost, Student perception, Learning result.

\section{PENDAHULUAN}

Pendidikan hal yang bersifat mutlak bagi setiap manusia dan tidak dapat dipisahkan dari kehidupan seseorang, keluarga maupun kehidupan berbangsa dan bernegara karena dunia pendidikan membentuk pribadi-pribadi yang tangguh, berkualitas dan memiliki ilmu pengetahuan. Dalam Undang-undang Dasar Republik Indonesia Tahun 1945 dalam Pasal 31 ayat (1) telah mengamatkan bahwa setiap warga Negara berhak untuk mendapatkan pendidikan dalam rangka mengembangkan potensi yang dimiliki secara utuh dan optimal. Upaya untuk melaksanakan amanat tersebut Pemerintah telah mengeluarkan kebijakan Undang-undang Nomor 20 Tahun 2003 tentang Sistem Pendidikan Nasional yang merupakan dasar hukum penyelenggaraan sistem pendidikan di Indonesia.

Berkenaan dengan penyelenggaraan sistem pendidikan di Indonesia, pemerintah menetapkan kebijakan melalui Peraturan Pemerintah No.19 tahun 2005 tentang Standar Nasional Pendidikan (SNP). Melalui SNP ini pemerintah menetapkan kriteria minimal yang harus dipenuhi pada sistem pendidikan di Indonesia. Kriteria minimal ini terdiri dari delapan standar pendidikan yang harus dipenuhi dalam proses pendidikan pada satuan pendidikan. 1. Standar Kompetensi Lulusan; 2. Standar Isi; 3. Standar Proses; 4. Standar pendidik dan tenaga kependidikan; 5. Standar sarana dan prasarana; 6. Standar pengelolaan; 7. Standar pembiayaan; 8. Standar penilaian pendidikan. Menurut Sudjana (2011) "Keberhasilan suatu proses belajar mengajar dapat dilihat dari hasil belajar yang dicapai oleh siswa". Dari pendapat tersebut indikator hasil belajar dalam penelitian ini dapat dilihat diantaranya dari hasil nilai ulangan harian (UH). Kondisi kualitas hasil belajar siswa SMA di Kota Mojokerto dapat di lihat dari rata-rata nilai ulangan harian yang diperoleh pada tahun ajaran 2014/2015 mengalami penurunan.

Berhasil tidaknya seorang siswa meraih prestasi belajarnya tergantung dari banyak hal atau tergantung dari faktor-faktor yang mempengaruhinya. Secara garis besar hasil belajar peserta didik dipengaruhi oleh faktor internal dan faktor eksternal. Slameto(2010) mengatakan bahwa hasil belajar peserta didik dipengaruhi oleh dua faktor utama yaitu faktor dari dalam diri peserta didik dan faktor dari luar peserta didik atau faktor lingkungan. Sedangkan menurut Purwanto(1996) hasil belajar dipengaruhi oleh faktor internal dan eksternal. Faktor internal adalah faktor yang berasal dari dalam diri siswa 
sendiri, yang meliputi faktor fisiologis dan faktor psikologis. Faktor fisiologis meliputi kondisi panca indra dan kesehatan, sedangkan faktor psikologis meliputi sikap, bakat, minat, intelegensi. Sedangkan faktor eksternal adalah faktor yang berasal dari luar diri siswa yang bersangkutan, meliputi faktor keluarga, faktor sekolah, dan faktor masyarakat.

Salah satu upaya yang dapat membantu pengembangan proses belajarmengajar agar bisa tercapai secara optimal menurut Wayan (2008) adalah dengan mengenali serta meneliti berbagai faktor yang mempengaruhi siswa dalam proses belajar mengajar. Hal ini nantinya diharapkan dapat menjadi referensi bagi guru untuk meningkatkan hasil belajar sehingga siswa memiliki prestasi yang baik. Salah satu faktor yang peneliti anggap berpengaruh terhadap hasil belajar siswa yaitu biaya pribadi (private cost). Menurut Supriadi (2003)Biaya pribadi (private cost) adalah pengeluaran keluarga untuk pendidikan atau dikenal juga pengeluaran rumah tangga (house expenditure) meliputi uang transportasi ke sekolah, pembelian peralatan sekolah (alat-alat tulis, dan buku), biaya kontrakan/kos, biaya kursus/les, uang saku/jajan, pembelian perlengkapan sekolah (tas, seragam, sepatu).

Tersedianya biaya yang memadai akan menghasilkan pendidikan yang berkualitas. Hal tersebut dipertegas oleh Fattah(2009) bahwa biaya dan mutu pendidikan mempunyai keterkaitan secara langsung. Faktor yang juga peneliti anggap sebagai faktor yang memiliki peran penting dalam meningkatkan hasil belajar siswa adalah persepsi dari siswa itu sendiri, sejalan dengan yang disampaikan oleh Slameto (2010) bahwa persepsi yang dimiliki itu bersifat selektif, dan seseorang memiliki kecenderungan-kecenderungan hanya memperhatikan beberapa rangsangan saja dari banyaknya rangsangan yang ada di sekelilingnya. Sehingga dapat disimpulkan bahwa siswa akan menerima suatu pelajaran dengan baik tergantung pada apa yang ia pernah pelajari, apa yang pada saat itu menarik perhatiannya dan ke arah mana persepsi yang dimilikinya mempunyai kecenderungan.

Menurut Warsita (2008) dalam pembelajaran yang ada di sekolah, perlu mengembangkan keseluruhan kecerdasan yang dimiliki siswa, untuk menjamin siswa menjadi juara, oleh karena itu dalam aplikasinya perlu adanya sumber belajar yang memadai. Hal lain yang dikeluhkan oleh siswa di SMAN Mojokerto adalah kurang tersedianya media pembelajaran yang menarik . Padahal dalam pendidikan, pemakaian media menurut Syukur (2008) sangat berkaitan dengan perkembangan psikologi belajar siswa. Hal tersebut mengakibatkan peran media dalam pendidikan saat ini sangatlah penting. Penelitian yang dilakukan oleh Stepp (2002), menunjukkan bahwa adanya perubahan teknologi pembelajaran mengakibatkan persepsi siswa semakin bertambah positif, artinya semakin baik pembelajaran yang dilakukan oleh guru akan semakin baik persepsi siswa dan pada akhirnya akan mempengaruhi hasil belajarnya.

\section{METODE PENELITIAN}

Jenis penelitian ini adalah penelitian asosiatif kausal. Penelitian asosiatif kausal merupakan jenis penelitian yang bertujuan untuk menganalisis hubungan antar variabel yang saling terkait satu sama lainnya yang 
menjelaskan bagaimana suatu variabel dapat mempengaruhi variabel lainnya (Sugiyono, 2011). Dalam penelitian ini bertujuan untuk menjelaskan pengaruh biaya pribadi (private cost) dan persepsi siswa tentang pembelajaran ekonomi materi akuntansi terhadap hasil belajar siswa kelas XI SMA Negeri se-Kota Mojokerto.Dalam penelitian ini terdiri dari dua variabel bebas yaitu biaya pribadi $\left(\mathrm{X}_{1}\right)$ dan persepsi siwa $\left(\mathrm{X}_{2}\right)$, dan satu variabel terikatnya yakni hasil belajar (Y). Dalam penelitian ini teknik sampling yang digunakan adalah Simple Random Sampling.Simple Random Sampling adalah teknik pengambilan anggota sampel dari populasi dilakukan secara acak tanpa memperhatikan strata yang ada dalam populasi itu (Sugiyono, 2010). Jadi dalam teknik simple random sampling setiap anggota dari populasi mempunyai kesempatan yang sama untuk dimasukkan ke dalam sampel. Cara yang digunakan dalam penelitian ini yaitu dengan menggunakan undian.Jumlah keseluruhan sampel pada penelitian ini adalah 255 siswa yang meliputi kelas XI Program Studi IPS di SMAN 1, SMAN 2 dan SMAN 3 Kota Mojokerto. Adapun metode pengumpulan data yang digunakan adalah metode kuesioner atau angket dan Teknik analisis data yang digunakan dalam penelitian ini adalah teknik analisis regresi berganda dengan persamaan resgresi $\mathrm{Y}=-5,245$ $+1,770 \mathrm{X}_{1}+0,368 \mathrm{X}_{2}+\mathrm{e}$.

\section{HASIL PENELITIAN DAN PEMBAHASAN}

Berdasarkan data dari variabel biaya pribadi $\left(\mathrm{X}_{1}\right)$ yang terdiri dari delapan indikator dapat dijelaskan sebagai berikut:

a. Biaya transportasi

Dari rekapitulasi jawaban angket terbuka indikator biaya transportasi diperoleh hasil sebagai berikut.

Tabel 1. Biaya Transportasi

\begin{tabular}{|c|c|c|c|}
\hline Biaya Transportasi & Kriteria & Jumlah Siswa & Prosentase \\
\hline $13000-15000$ & Sangat Tinggi & 27 Siswa & $11 \%$ \\
\hline $11000-13000$ & Tinggi & 13 Siswa & $5 \%$ \\
\hline $9000-11000$ & Sedang & 13 Siswa & $5 \%$ \\
\hline $7000-9000$ & Rendah & 105 Siswa & $41 \%$ \\
\hline $5000-7000$ & Sangat Rendah & 97 Siswa & $38 \%$ \\
\hline Total & & 255 Siswa & $100 \%$ \\
\hline
\end{tabular}

Berdasarkan table 1 diperoleh bahwa rata-rata pengeluaran siswa untuk biaya transportasi ke sekolah tergolong rendah dengan prosentase $41 \%$ siswa mengeluarkan uang untuk transportasi sebesar Rp 7.000 sampai dengan 9.000 .

b. Tas Sekolah

Dari rekapitulasi jawaban angket terbuka indikator pengeluaran tas sekolah diperoleh hasil sebagai berikut. 
Tabel 2. Tas Sekolah

\begin{tabular}{|c|l|l|c|}
\hline $\begin{array}{c}\text { Biaya Pembelian } \\
\text { Tas }\end{array}$ & \multicolumn{1}{|c|}{ Kriteria } & Jumlah Siswa & Prosentase \\
\hline $170.000-200.000$ & Sangat Tinggi & 12 Siswa & $4,71 \%$ \\
\hline $140.000-170.000$ & Tinggi & 59 Siswa & $23,14 \%$ \\
\hline $110.000-140.000$ & Sedang & 34 Siswa & $13,33 \%$ \\
\hline $80.000-110.000$ & Rendah & 112 Siswa & $43,92 \%$ \\
\hline $50.000-80.000$ & Sangat Rendah & 38 Siswa & $14,90 \%$ \\
\hline Total & & 255 Siswa & $\mathbf{1 0 0} \%$ \\
\hline
\end{tabular}

Berdasarkan tabel 2 diperoleh bahwa rata-rata pengeluaran siswa untuk pembelian tas sekolah tergolong rendah dengan prosentase $43,92 \%$ siswa mengeluarkan uang untuk pembelian tas sekolah berkisar antara Rp 80.000 sampai dengan $\mathrm{Rp} 110.000$.

c. Seragam Sekolah

Dari rekapitulasi jawaban angket terbuka indikator pengeluaran untuk seragam sekolah diperoleh hasil sebagai berikut.

Tabel 3. Seragam Sekolah

\begin{tabular}{|c|l|ll|c|}
\hline $\begin{array}{c}\text { Biaya Pembelian } \\
\text { Seragam }\end{array}$ & \multicolumn{1}{|c|}{ Kriteria } & Jumlah Siswa & Prosentase \\
\hline $170.000-200.000$ & Sangat Tinggi & 45 & Siswa & $17,65 \%$ \\
\hline $140.000-170.000$ & Tinggi & 81 & Siswa & $31,76 \%$ \\
\hline $110.000-140.000$ & Sedang & 113 & Siswa & $44,31 \%$ \\
\hline $80.000-110.000$ & Rendah & 9 & Siswa & $3,53 \%$ \\
\hline $50.000-80.000$ & Sangat Rendah & 7 & Siswa & $2,75 \%$ \\
\hline Total & & $\mathbf{2 5 5}$ Siswa & $\mathbf{1 0 0} \%$ \\
\hline
\end{tabular}

Berdasarkan table 3 diperoleh bahwa rata-rata pengeluaran siswa untuk pembelian seragam sekolah tergolong sedang dengan prosentase $44,31 \%$ siswa mengeluarkan uang untuk pembelian seragam sekolah berkisar antara Rp 110.000 sampai dengan Rp 140.000.

d. Sepatu

Dari rekapitulasi jawaban angket terbuka indikator pengeluaran untuk sepatu sekolah diperoleh hasil sebagai berikut.

Tabel 4. Sepatu Sekolah

\begin{tabular}{|c|l|l|c|}
\hline $\begin{array}{c}\text { Biaya Pembelian } \\
\text { Sepatu }\end{array}$ & \multicolumn{1}{|c|}{ Kriteria } & Jumlah Siswa & Prosentase \\
\hline $196.000-220.000$ & Sangat Tinggi & 51 Siswa & $20 \%$ \\
\hline $172.000-196.000$ & Tinggi & 74 Siswa & $29,02 \%$ \\
\hline $148.000-172.000$ & Sedang & 8 Siswa & $3,14 \%$ \\
\hline $124.000-148.000$ & Rendah & 118 Siswa & $46,27 \%$ \\
\hline $100.000-124.000$ & Sangat Rendah & 4 Siswa & $1,57 \%$ \\
\hline Total & & $\mathbf{2 5 5}$ Siswa & $\mathbf{1 0 0} \%$ \\
\hline
\end{tabular}


Berdasarkan tabel 4 diperoleh bahwa rata-rata pengeluaran siswa untuk pembelian sepatu sekolah tergolong rendah dengan prosentase $46,27 \%$ siswa mengeluarkan uang untuk pembelian sepatu sekolah berkisar antara Rp 124.000 sampai dengan Rp 148.000.

e. Buku Penunjang Mata Pelajaran Akuntansi

Dari rekapitulasi jawaban angket terbuka indikator pengeluaran untuk pembelian buku penunjang pelajaran akuntansi diperoleh hasil sebagai berikut.

Tabel 5. Buku Penunjang Mata Pelajaran Akuntansi

\begin{tabular}{|l|l|l|c|}
\hline $\begin{array}{c}\text { Pembelian Buku } \\
\text { Penunjang }\end{array}$ & \multicolumn{1}{|c|}{ Kriteria } & Jumlah Siswa & Prosentase \\
\hline $89.000-100.000$ & Sangat Tinggi & 73 Siswa & $28,63 \%$ \\
\hline $78.000-89.000$ & Tinggi & 102 Siswa & $40 \%$ \\
\hline $67.000-78.000$ & Sedang & 25 Siswa & $9,8 \%$ \\
\hline $56.000-67.000$ & Rendah & 27 Siswa & $10,59 \%$ \\
\hline $45.000-56.000$ & Sangat Rendah & 18 Siswa & $7,06 \%$ \\
\hline Total & & 255 Siswa & $\mathbf{1 0 0} \%$ \\
\hline
\end{tabular}

Berdasarkan tabel 5 diperoleh bahwa rata-rata pengeluaran siswa untuk pembelian buku penunjang pelajaran akuntansi tergolong tinggi dengan prosentase $40 \%$ siswa mengeluarkan uang untuk pembelian buku berkisar antara Rp 78.000 sampai dengan Rp 89.000.

f. Pembelian Alat Tulis

Dari rekapitulasi jawaban angket terbuka indikator pengeluaran untuk pembelian alat tulis diperoleh hasil sebagai berikut.

Tabel 6. Pembelian Alat Tulis

\begin{tabular}{|c|l|l|c|}
\hline $\begin{array}{c}\text { Pembelian Alat } \\
\text { Tulis }\end{array}$ & \multicolumn{1}{|c|}{ Kriteria } & Jumlah Siswa & Prosentase \\
\hline $42.000-50.000$ & Sangat Tinggi & 45 Siswa & $7,65 \%$ \\
\hline $34.000-42.000$ & Tinggi & 112 Siswa & $43,92 \%$ \\
\hline $26.000-34.000$ & Sedang & 80 Siswa & $31,37 \%$ \\
\hline $18.000-26.000$ & Rendah & 13 Siswa & $5,1 \%$ \\
\hline $10.000-18.000$ & Sangat Rendah & 15 Siswa & $5,88 \%$ \\
\hline Total & & 255 Siswa & $\mathbf{1 0 0} \%$ \\
\hline
\end{tabular}

Berdasarkan tabel 6 diperoleh bahwa rata-rata pengeluaran siswa untuk pembelian alat tulis tergolong tinggi dengan prosentase 43,92 \% siswa mengeluarkan uang untuk pembelian buku berkisar antara $\mathrm{Rp} 34.000$ sampai dengan Rp 42.000.

g. Uang Saku

Dari rekapitulasi jawaban angket terbuka indikator pengeluaran untuk saku 
atau jajan diperoleh hasil sebagai berikut.

Tabel 7. Uang saku atau jajan

\begin{tabular}{|c|c|c|c|}
\hline Uang Saku & Kriteria & Jumlah Siswa & Prosentase \\
\hline $17.000-20.000$ & Sangat Tinggi & 15 Siswa & $5,88 \%$ \\
\hline $14.000-17.000$ & Tinggi & 12 Siswa & $4,71 \%$ \\
\hline $11.000-14.000$ & Sedang & 212 Siswa & $83,14 \%$ \\
\hline $8.000-11.000$ & Rendah & Siswa & $3,53 \%$ \\
\hline $5.000-8.000$ & Sangat Rendah & Siswa & $2,75 \%$ \\
\hline Total & & 255 Siswa & $100 \%$ \\
\hline
\end{tabular}

Berdasarkan tabel 7 diperoleh bahwa rata-rata pengeluaran siswa untuk uang saku atau uang jajan tergolong sedang dengan prosentase 83,14\% siswa mengeluarkan uang untuk pembelian buku berkisar antara Rp 11.000 sampai dengan $\mathrm{Rp} 14.000$.

h. Pengeluaran Untuk Pulsa

Dari rekapitulasi jawaban angket terbuka indikator pengeluaran untuk pembelian pulsa yang digunakan untuk internet diperoleh hasil sebagai berikut

Tabel 8 Pembelian pulsa

\begin{tabular}{|c|l|l|c|}
\hline Pulsa Internet & \multicolumn{1}{|c|}{ Kriteria } & Jumlah Siswa & Prosentase \\
\hline $86.000-100.000$ & Sangat Tinggi & 69 Siswa & $27,06 \%$ \\
\hline $72.000-86.000$ & Tinggi & 117 Siswa & $45,88 \%$ \\
\hline $68.000-72.000$ & Sedang & 25 Siswa & $9,8 \%$ \\
\hline $44.000-68.000$ & Rendah & 31 Siswa & $12,16 \%$ \\
\hline $30.000-44.000$ & Sangat Rendah & 13 Siswa & $5,1 \%$ \\
\hline \multicolumn{2}{|c|}{ Total } & $\mathbf{2 5 5}$ Siswa & $\mathbf{1 0 0 \%}$ \\
\hline
\end{tabular}

Berdasarkan tabel 8 diperoleh bahwa rata-rata pengeluaran siswa untuk pembelian pulsa yang digunakan untuk internet tergolong tinggi dengan prosentase $45,88 \%$ siswa mengeluarkan uang untuk pembelian pulsa berkisar antara $\mathrm{Rp} 72.000$ sampai dengan $\mathrm{Rp}$ 86.000. Untuk variabel persepsi siswa tentang pembelajaran ekonomi $\left(\mathrm{X}_{2}\right)$ yang terdiri dari dua indicator diantaranya yaitu persepsi siswa terhadap media pembelajaran dan persepsi siswa terhadap sumber belajar dapat dijelaskan sebagai berikut:

Pada sub variable persepsi siswa tentang media pembelajaran terdiri dari 7 item pertanyaan. Jumlah nilai jawaban responden untuk ketujuh item pertanyaan tersebut adalah $1122+1063+1090+1127+1061+1041+$ $1088=7592$. Sedangkan skor idealnya adalah 5 × 7 × $255=8925$. Jadi perhitungan persentasenya adalah sebagai berikut:

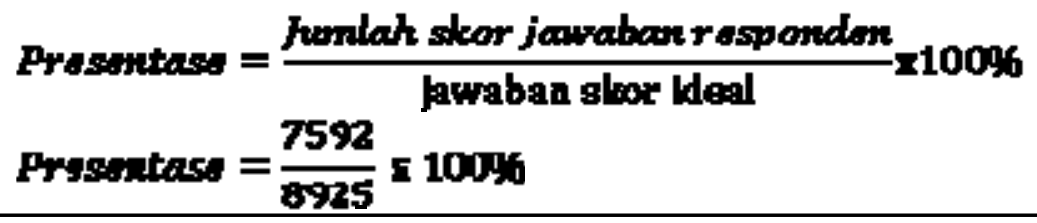




\section{Praserctass $=85,06 \%$}

Dari perhitungan di atas maka dapat disimpulkan bahwa persepsi siswa tentang sumber media pembelajaran termasuk dalam kategori sangat tinggi. Pada sub variable persepsi siswa tentang sumber belajar terdiri dari 8 item pertanyaan. Jumlah nilai jawaban responden untuk kedelapan item pertanyaan tersebut adalah $1076+1052+1118+1030+1062+1102+$ $1118+1152=8710$. Sedangkan skor idealnya adalah 5 × 8 × $255=10.200$. Jadi perhitungan persentasenya adalah sebagai berikut:

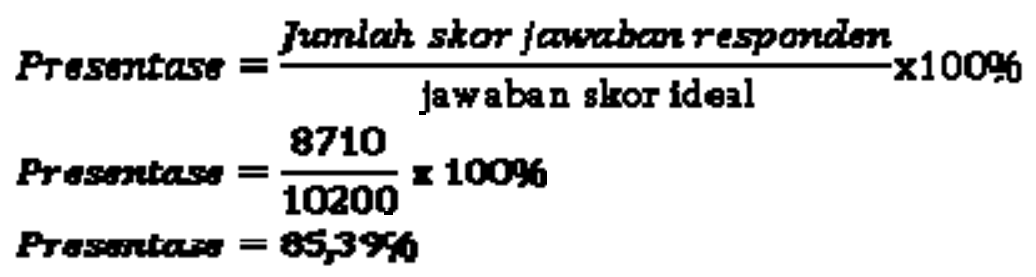

Dari perhitungan di atas maka dapat disimpulkan bahwa persepsi siswa tentang sumber belajar termasuk dalam kategori sangat tinggi. Sedangkan data hasil belajar siswa (Y) yang diperoleh dari ketiga sekolah yaitu SMAN 1, SMAN 2, dan SMAN 3 diketahui rata-rata hasil belajar dari masingmasing sekolah tersebut adalah sebagai berikut:

Tabel 9. Rata-rata Hasil Belajar

\begin{tabular}{|c|l|c|}
\hline No & \multicolumn{1}{|c|}{ Nama Sekolah } & $\begin{array}{c}\text { Rata-rata Hasil } \\
\text { Belajar }\end{array}$ \\
\hline 1 & SMAN 1 & 79,04 \\
\hline 2 & SMAN 2 & 78,67 \\
\hline 3 & SMAN 3 & 78,76 \\
\hline
\end{tabular}

Dari tabel di atas diketahui bahwa hasil belajar siswa SMAN 1 lebih tinggi dibandingkan SMAN 2 dan SMAN 3.

Penelitian ini menggunakan analisis regresi berganda yang berfungsi untuk mengetahui ada tidaknya pengaruh antara ketiga variabel yaitu biaya pribadi $\left(\mathrm{X}_{1}\right)$, persepsi siswa tentang pembelajaran ekonomi $\left(\mathrm{X}_{2}\right)$, terhadap hasil belajar siswa (Y). Untuk mengetahui variabel bebas terhadap variabel terikat dilakukan analisis regresi linier berganda dengan persamaan regresi pada tabel dibawah ini:

Tabel 10. Output Model Regresi

Coefficients $^{\mathrm{a}}$

\begin{tabular}{|c|c|c|c|c|c|c|}
\hline \multirow{2}{*}{\multicolumn{2}{|c|}{ Model }} & \multicolumn{2}{|c|}{ Unstandardized Coefficients } & \multirow{2}{*}{$\begin{array}{c}\begin{array}{c}\text { Standardized } \\
\text { Coefficients }\end{array} \\
\text { Beta }\end{array}$} & \multirow[b]{2}{*}{$\mathrm{t}$} & \multirow[b]{2}{*}{ Sig. } \\
\hline & & $\mathrm{B}$ & Std. Error & & & \\
\hline \multirow[t]{3}{*}{1} & (Constant) & -5.245 & 2.240 & & -2.341 & .020 \\
\hline & PRIVATE_COST & 1.770 & .069 & .774 & 25.775 & .000 \\
\hline & PERSEPSI & .368 & .050 & .219 & 7.283 & .000 \\
\hline
\end{tabular}

a. Dependent Variable: HASIL_BELAJAR 
Berdasarkan tabel 10, maka model persamaan regresi dapat ditulis dalam bentuk persamaan regresi linier berganda sebagai berikut: $\mathrm{Y}=-5,245+1,770$ $\mathrm{X}_{1}+0,368 \mathrm{X}_{2}+$ e. Hasil persamaan analisis regresi linier berganda di atas dapat diinterpretasikan sebagai berikut:

a. Nilai konstanta (a) sebesar -5,245 artinya bahwa menunjukkan pengaruh yang negative terhadap hasil belajar. Apabila dengan menganggap semua variabel bebas sama dengan 0, maka hasil belajar (Y) sebesar -5.245.

b. Koefisien biaya pribadi ( $\left.b_{1}\right)$ sebesar 1,770 artinya bahwa setiap peningkatan satu persen biaya pribadi pada hasil belajar akan mengalami peningkatan sebesar 1,770. Dalam hal ini faktor lain yang mempengaruhi hasil belajar dianggap tetap.

c. Koefisien persepsi siswa tentang pembelajaran ekonomi $\left(b_{2}\right)$ sebesar 0,368 artinya bahwa setiap peningkatan satu persen persepsi siswa tentang pembelajaran ekonomi maka hasil belajar akan mengalami peningkatan sebesar 0,368. Dalam hal ini faktor lain yang mempengaruhi hasil belajar dianggap tetap.

Uji $\mathrm{t}$ statistic digunakan untuk mengetahui pengaruh masing-masing variabel bebas terhadap variabel terikat yaitu pengaruh secara parsial biaya pribadi dan persepsi siswa tentang pembelajarn ekonomi terhadap hasil belajar siswa kelas XI IPS SMAN Se- Kota Mojokerto, maka pada penelitian ini dilakukan uji t, berikut ini tabel hasil uji $t$ :

Tabel 11. Hasil Uji t

Coefficients $^{\mathrm{a}}$

\begin{tabular}{|c|c|c|c|c|c|}
\hline \multirow[b]{2}{*}{ Model } & \multicolumn{2}{|c|}{ Unstandardized Coefficients } & \multirow{2}{*}{$\begin{array}{c}\begin{array}{c}\text { Standardized } \\
\text { Coefficients }\end{array} \\
\text { Beta } \\
\end{array}$} & \multirow[b]{2}{*}{$\mathrm{t}$} & \multirow[b]{2}{*}{ Sig. } \\
\hline & $\mathrm{B}$ & Std. Error & & & \\
\hline (Constant) & -5.245 & 2.240 & & -2.341 & .020 \\
\hline PRIVATE_COST & 1.770 & .069 & .774 & 25.775 & .002 \\
\hline PERSEPSI & .368 & .050 & .219 & 7.283 & .000 \\
\hline
\end{tabular}

a. Dependent Variable: HASIL_BELAJAR

Berdasarkan tabel 11 dapat dilihat bahwa nilai signifikan masing-masing variabel bebas dimana $\left(\mathrm{X}_{1}\right)$ biaya pribadi memiliki thitung $=25,775>1,65$ signifikansi $(\mathrm{sig})=0,002<$ taraf signifikansi $\alpha=0,05$, maka dapat disimpulkan bahwa ada pengaruh yang positif dan signifikan biaya pribadi terhadap hasil belajar siswa kelas XI IPS SMAN Se- Kota Mojokerto. Hal ini berarti bahwa biaya pribadi secara parsial berpengaruh signifikan positif terhadap hasil belajar sehingga hipotesis ke-1 penelitian ini diterima.

Berdasarkan kedelapan jenis pengeluaran siswa yang termasuk kedalam biaya pribadi (private cost) ; (1) biaya transportasi rata-rata dari ketiga sekolah tergolong dalam kriteria rendah dengan hasil jawaban angket dari 105 siswa menjawab pengeluarannya berkisar Rp. 7000-9.000, (2) pembelian tas sekolah dari ketiga sekolah tergolong dalam kriteria rendah dengan hasil jawaban angket dari 112 siswa menjawab pengeluarannya berkisar Rp. 80.000-110.000, (3) pembelian seragam sekolah dari ketiga sekolah tergolong dalam kriteria sedang dengan hasil jawaban angket dari 113 siswa menjawab pengeluarannya berkisar Rp. 110.000-140.000 , (4) pembelian sepatu dari ketiga sekolah tergolong dalam kriteria rendah dengan hasil jawaban angket dari 118 siswa 
menjawab pengeluarannya berkisar Rp. 124.000-148.000, (5) pembelian buku penunjang mata pelajaran akuntansi dari ketiga sekolah tergolong dalam kriteria tinggi dengan hasil jawaban angket dari 102 siswa menjawab pengeluarannya berkisar Rp. 78.000- Rp. 89.000, (6) pembelian alat tulis dari ketiga sekolah tergolong dalam kriteria tinggi dengan hasil jawaban angket dari 112 siswa menjawab pengeluarannya berkisar Rp. 34.000- Rp. 42.000, (7) pengeluaran uang saku dari ketiga sekolah tergolong dalam kriteria sedang dengan hasil jawaban angket dari 212 siswa menjawab pengeluarannya berkisar Rp. 11.000- Rp. 14.000, (8) pembelian pulsa dari ketiga sekolah tergolong dalam kriteria tinggi dengan hasil jawaban angket dari 117 siswa menjawab pengeluarannya berkisar Rp. 72000- Rp. 86.000. Dari kedelapan jenis pengeluaran siswa diatas dapat diperoleh hasil bahwa biaya pribadi siswa tergolong tinggi, hal ini berpengaruh pada hasil belajarnya. Hal ini memberikan pengertian bahwa biaya pribadi (private cost) dan hasil belajar memiliki hubungan yang searah. Semakin tinggi atau positif biaya pribadi (private cost) maka akan diiringi dengan meningkatnya hasil belajar. Demikian pula sebaliknya, semakin rendah atau negatif biaya pribadi (private cost) maka semakin rendah hasil belajar.

Hasil penelitian ini berbanding lurus dengan hasil penelitian yang dilakukan oleh Nishimura (2008), Suhirman (2012) dan Soraya (2013) yang mendapati bahwa biaya pribadi (private cost) berpengaruh terhadap hasil belajar dan keduanya memiliki hubungan yang positif. Siswa dengan biaya pribadi yang berasal dari ekonomi lemah akan berakibat pada hasil belajar yang tidak maksimal. Hal ini terjadi karena lemahnya dukungan ekonomi sehingga segala fasilitas pendukung belajar tidak terpenuhi, akibatnya siswa tidak bisa belajar secara maksimal.

Sedangkan Variabel $\left(\mathrm{X}_{2}\right)$ persepsi siswa tentang pembelajaran ekonomi memiliki thitung $=7,283>1,65$ signifikansi $(\mathrm{sig})=0,000<$ taraf signifikansi $\alpha$ $=0,05$, maka dapat disimpulkan bahwa ada pengaruh yang positif dan signifikan persepsi siswa tentang pembelajaran ekonomi terhadap hasil belajar siswa kelas XI IPS SMAN Se- Kota Mojokerto. Hal ini berarti bahwa persepsi siswa tentang pembelajaran ekonomi berpengaruh signifikan positif terhadap hasil belajar sehingga hipotesis ke-2 penelitian ini diterima. Hal ini menunjukkan bahwa persepsi siswa tentang pembelajaran ekonomi memiliki hubungan yang berbanding lurus, artinya semakin positif atau tinggi persepsi siswa tentang pembelajaran ekonomi maka akan berimplikasi pada peningkatan hasil belajar siswa. Begitupun sebaliknya, semakin rendah tingkat persepsi siswa tentang pembelajaran ekonomi maka akan diiringi dengan penurunan hasil belajar siswa.

Pada sub variabel persepsi siswa tentang media pembelajaran terdiri dari 7 item pertanyaan. Jumlah nilai jawaban responden untuk ketujuh item pertanyaan tersebut adalah $1122+1063+1090+1127+1061+1041+1088$ $=7592$. Sedangkan skor idealnya adalah $5 \times 7 \times 255=8925$. Hasil dari perhitungannya menghasilkan persentase sebesar $85,06 \%$. maka dapat disimpulkan bahwa persepsi siswa tentang sumber media pembelajaran termasuk dalam kategori sangat tinggi. Sedangkan pada sub sub variabel persepsi siswa tentang sumber belajar terdiri dari 8 item pertanyaan. Jumlah nilai jawaban responden untuk kedelapan item pertanyaan tersebut adalah 1076 
$+1052+1118+1030+1062+1102+1118+1152=8710$. Sedangkan skor idealnya adalah $5 \times 8 \times 255=10.200$. Hasil dari perhitungannya menghasilkan persentase sebesar $85,39 \%$. Maka dapat disimpulkan bahwa persepsi siswa tentang sumber media pembelajaran termasuk dalam kategori sangat tinggi.

Hasil penelitian ini sejalan dengan penelitian yang dilakukan oleh Doppelt dan Christian (2008), Jennie (2010), Somenarain (2010), Sumarini dan Yuli (2013) dan James (2014) yang menyatakan bahwa persepsi siswa tentang pembelajaran yang posititif akan mampu meningkatkan perhatiannya dan lebih bersemangat terhadap apa yang diajarkan sehingga pada akhirnya akan berpengaruh terhadap hasil belajar siswa. Dalam beberapa penelitian tersebut menggambarkan bahwa untuk mencapai hasil belajar yang tinggi dapat dilakukan dengan menggali berbagai sumber belajar yang tidak hanya terbatas pada bahan ajar atau tesk tertulis saja, namun bisa juga melalui lingkungan, teknologi dan media sebagai sumber belajar.

Uji F digunakan untuk menguji hipotesis yang melibatkan lebih dari satu koefisien (Sarwoko, 2005). Uji F ini bertujuan untuk menunjukkan apakah semua variabel independen yaitu biaya pribadi dan persepsi siswa tentang pembelajaran ekonomi yang dimasukkan ke dalam model mempunyai pengaruh secara bersama-sama terhadap variabel dependen yaitu hasil belajar. Adapun hasil uji F dengan SPSS 22 for windows adalah sebagai berikut:

Tabel 12. Hasil uji F

ANOVA $^{\mathrm{a}}$

\begin{tabular}{|ll|r|r|r|r|r|}
\hline \multicolumn{1}{|l|}{ Model } & \multicolumn{1}{c|}{$\begin{array}{c}\text { Sum of } \\
\text { Squares }\end{array}$} & df & Mean Square & \multicolumn{1}{c|}{$\mathrm{F}$} & Sig. \\
\hline 1 & Regression & 46544.831 & 2 & 23272.415 & 955.854 & $.000^{\mathrm{b}}$ \\
& Residual & 6135.507 & 252 & 24.347 & & \\
& Total & 52680.337 & 254 & & & \\
\hline
\end{tabular}

Dari hasil nilai $F_{h i t u n g}$ sebesar 955,854 dengan signifikansi kurang dari $5 \%$ yaitu 0,000 . Maka dapat disimpulkan bahwa biaya pribadi $\left(\mathrm{X}_{1}\right)$ dan persepsi siswa tentang pembelajaran ekonomi $\left(\mathrm{X}_{2}\right)$ secara simultan berpengrauh signifikan positif terhadap hasil belajar (Y) sehingga hipotesis ke3 penelitian ini diterima.

Seberapa besar pengaruh variabel independen yaitu biaya pribadi terhadap variabel dependen yaitu hasil belajar dapat dilihat melalui adjusted Rsquare. Adapun hasil analisis data dengan SPSS 22 for window sebagai berikut:

Tabel 13. Koefisien Determinasi

Model Summary

\begin{tabular}{|c|c|c|c|c|}
\hline Model & $\mathrm{R}$ & R Square & Adjusted R Square & $\begin{array}{l}\text { Std. Error of the } \\
\text { Estimate }\end{array}$ \\
\hline 1 & $.940^{a}$ & .884 & .883 & 4.93429 \\
\hline
\end{tabular}


Dari tabel di atas dapat diketahui bahwa nilai adjusted R-square sebesar 0,883 . Hal ini menggambarkan bahwa hasil belajar dipengaruhi oleh biaya pribadi dan persepsi siswa tentang pembelajaran ekonomi sebesar 88,3\% sedangkan $11,7 \%$ dipengaruhi oleh faktor-faktor lain selain variabel penelitian tersebut.

Hasil penelitian ini sejalan dengan hasil penelitian yang dilakukan oleh Nishimura (2008), Suhirman (2012) dan Soraya (2013) yang mendapati bahwa biaya pribadi (private cost) berpengaruh terhadap hasil belajar serta penelitian yang dilakukan oleh Doppelt dan Christian (2008), Jennie (2010), Somenarain (2010), Sumarini dan Yuli (2013) dan James (2014) yang menyatakan bahwa persepsi siswa berpengaruh terhadap hasil belajar siswa. Dengan demikian, hipotesis yang menyatakan bahwa ada pengaruh antara biaya pribadi (private cost) dan persepsi siswa tentang pembelajaran ekonomi terhadap hasil belajar diterima atau terbukti kebenarannya.

\section{SIMPULAN}

Hasil pengujian yang pertama menunjukkan bahwa biaya pribadi $\left(\mathrm{X}_{1}\right)$ berpengaruh signifikan terhadap hasil belajar siswa (Y) kelas XI IPS SMAN 1, SMAN 2, dan SMAN 3 Kota Mojokerto. Delapan indikator biaya pribadi, yang termasuk pada kategori rendah yaitu indikator biaya transportasi, pengeluaran untuk pembelian tas dan sepatu, sedangkan indikator yang termasuk pada kategori sedang yaitu pengeluaran untuk pembelian sragam, dan uang saku, untuk ketiga indikator yaitu pembelian buku penunjang akuntansi, pembelian alat tulis, dan pembelian untuk pulsa tergolong dalam kategori tinggi.

Hasil pengujian yang kedua menunjukkan bahwa persepsi siswa tentang pembelajaran ekonomi $\left(\mathrm{X}_{2}\right)$ berpengaruh signifikan terhadap hasil belajar siswa (Y) kelas XI IPS SMAN 1, SMAN 2, dan SMAN 3 Kota Mojokerto. Indikator persepsi siswa tentang media pembelajaran dalam kategori sangat tinggi karena siswa sangat senang dengan menggunakan media, guru sering menggunaan media dan kebermanfaatan media sangat membantu mempermudah siswa memahami materi akuntansi. Sedangkan indikator persepsi siswa tentang sumber belajar dalam kategori sangat tinggi karena guru sangat membantu dalam memberikan berbagai informasi, tersedia fasilitas perpustakaan dan laboratorium komputer yang didukung wifi serta buku teks yang lengkap .

Sedangkan hasil pengujian yang ketiga menunjukkan bahwa biaya pribadi $\left(\mathrm{X}_{1}\right)$ dan persepsi siswa tentang pembelajaran ekonomi $\left(\mathrm{X}_{2}\right)$ berpengaruh signifikan terhadap hasil belajar siswa (Y) kelas XI IPS SMAN 1, SMAN 2, dan SMAN 3 Kota Mojokerto. Hal ini menggambarkan bahwa kedua variabel independen tersebut memiliki pengaruh terhadap hasil belajar siswa. Hasil temuan menunjukkan bahwa ke delapan indikator biaya pribadi dan dua indikator persepsi siswa tentang pembelajaran ekonomi merupakan pendukung dalam pencapaian hasil belajar siswa.

Berdasarkan hasil penelitian yang telah dijabarkan sebelumnya, maka peneliti merekomendasikan beberapa saran berkaitan dengan persepsi siswa tentang media pembelajaran disarankan sekolah tetap menyediakan dan menambah media pembelajaran untuk proses belajar mengajar dan guru lebih trampil lagi, kreatif dan selalu aktif menggunakan media pembelajaran. 
Sedangkan berkaitan dengan persepsi siswa tentang sumber belajar disarankan sekolah tetap mempertahankan fasilitas yang sudah lengkap seperti tersedia perpustakaan, lap komputer dan buku teks atau bacaan.

\section{DAFTAR RUJUKAN}

Departemen Pendidikan Nasional. (2003). Undang-Undang Republik Indonesia Nomor 20 Tahun 2003 Tentang Sistem Pendidikan Nasional. Jakarta: CV Ekajaya.

Doppelt, Yaron dan Christian D. Schunn. (2008). Identifying students' perceptions of the important classroom features affecting learning aspects of a design-based learning environment. (Online). DOI 10.1007/s10984008-9047-2. Journalof Faculty of Educational Sciences. Media B.V. Vol.2

Fattah, Nanang. 2009. Ekonomi dan Pembiayaan Pendidikan. Bandung: Remaja Rosda Karya

James Birt. 2014. Mixed media visualization effect on student perceptions and learning outcomes. Journal Education \& Technology (Online) Vol. 2 pp. (514-518).

Jennie, Jahnke. 2010. Student perceptions of the impact of online discussion forum participation on learning outcomes. Journal of Learning Design Vol. 3 Number. 2.

Nishimura, Mikiko. (2008).Impacts of the universal primary education policy on educational attainment and private costs in rural Uganda. Journal Economic Education V01. 28 pages 161-175.

Peraturan Menteri Pendidikan Nasional No. 16 tahun 2007. Kompetensi Guru . Jakarta: Depdiknas

Peraturan Pemerintah No. 19 tahun 2005. Standart Nasional Pendidikan . Jakarta: Depdiknas

Permen Diknas RI Nomor 41 Tahun 2007. Standar Proses Untuk Satuan Pendidikan Dasar dan Menengah. Jakarta: Depdiknas.

Purwanto, Ngalim. (1996) . PrinsipdanTeknikEvaluasiPengajaran. Bandung: PT. Remaja Rosdakarya.

Sarwoko, Suyantoro Sigit. (2005). Statistik inferensi: Untuk Ekonomi dan Bisnis. Jakarta. Andi.

Slameto. (2010). Belajar dan Faktor-Faktor yang Mempengaruhi. Jakarta: PT.Rineka Cipta

Somenarain, Latchman. (2010). Student Perceptions and Learning Outcomes in Asynchronous and Synchronous Online Learning Environments in a Biology Course. MERLOT Journal of Online Learning and Teaching Vol. 6, Number. 2. 
Soraya. 2013. Pengaruh Pembiayaan Pendidikan Oleh Orang Tua Terhadap Prestasi Belajar Siswa Kelas X SMA Negeri . (Online) artikel penelitian. Universitas Tanjungpura Pontianak. ((http://google.comDiakses 24 April 2015)

Steep, Jonita dan Greany. (2002). Student Perceptions On Language Learning In A Technological Environment: Implications For The New Millennium. Journal Language Learning \& Technology (Online). Vol. 6 No.1 PP. 165-180, Januari 2002. (http://google.com Diakses 23 Mei 2015

Sudjana, Nana. (2011). Penilaian Hasil PBM. Bandung: Remaja Rosda Karya

Sugiyono, 2011.MetodePenelitianManajemen. Bandung. Alfabeta.

Sugiyono. (2010) .Metode Penelitian Kuantitatif Kualitatif dan $R \& D$. Bandung.Alfabeta

Suhirman. 2012. Pengaruh biaya pendidikan terhadap hasil belajar melalui proses belajar mengajar di SMA Negeri Se-Kabupaten Rembang.Jurnal penelitian pendidikan ekonomi JEE 1 (2) (2012)

Sumarini, Sri dan Yuli Ekawati. (2013). Pengaruh Motivasi belajar, Sikap dan Persepsi Siswa Pada Pembelajaran Ekonomi Terhadap Hasil Belajar Di SMA Negeri 9 Pontianak Timur. (Online) Jilid 37.1

Supriadi, Dedi. (2003) . Satuan Biaya Pendidikan Dasar Dan Menengah. Bandung: Remaja Rosdakarya.

Syukur, Fatah NC. Dan Nor, Mohammad Ichwan (Eds). (2008). Teknologi Pendidikan. Semarang: Rasail Media Group

Warsita, Bambang. (2008). Teknologi Pembelajaran Landasan \& Aplikasinya. Jakarta: PT. Rineka Cipta.

Wayan, I Dwija. (2008). Hubungan Antara Konsep Diri, Motivasi Berprestasi dan Perhatian Orang tua Dengan Hasil Siswa Kelas II Sekolah Menengah Atas Unggulan di Kota Amlapura. Jurnal Pendidikan dan Pengajaran Undhiksa (Online). Vol XXXXI No. 1, Januari 2008. (http://google.com. Diakses 23 Mei 2015) 